\title{
Implementing ecological intensification in fish farming: definition and principles from contrasting experiences
}

\author{
Aubin Joël 1, ${ }^{*}$, Callier Myriam ${ }^{2}$, Rey-Valette Helene ${ }^{3}$, Mathe Syndhia ${ }^{4}$, Wilfart Aurelie ${ }^{1}$, \\ Legendre Marc ${ }^{5}$, Slembrouck Jacques ${ }^{5}$, Caruso Domenico ${ }^{5}$, Chia Eduardo ${ }^{4}$, Masson Gerard 6 , \\ Blancheton Jean-Paul ${ }^{2}$, Ediwarman ${ }^{7}$, Haryadi Joni ${ }^{8}$, Prihadi Tri Heru ${ }^{8}$, Casaca Jorge De Matos ${ }^{9}$, \\ Tamassia Sergio T. J. ${ }^{9}$, Tocqueville Aurelien ${ }^{10}$, Fontaine Pascal ${ }^{11}$
}

1 INRA, AGROCAMPUS OUEST, UMR, SAS, Rennes, France.

2 Univ Montpellier, CNRS, UMR, IFREMER,MARBEC,IRD, Palavas Les Flots, France.

3 Univ Montpellier, LAMETA, UMR, Montpellier, France.

4 INRA, CIRAD, UMR Innovat, Montpellier, France.

5 Univ Montpellier, CNRS, UMR, IRD,EPHE,ISE M, Montpellier, France.

6 Univ Lorraine, LIEC, UMR, Metz, France.

7 BBAT, Jambi, Indonesia.

${ }^{8}$ Agcy Marine \& Fisheries Res \& Dev, Jakarta, Indonesia.

9 EPAGRI, Chapeco, SC, Brazil.

10 ITAVI, Serv Aquaculture, Rouen, France.

11 Univ Lorraine, INRA, USC 340, UR AFPA, Vandoeuvre Les Nancy, France.

*Corresponding author : Joël Aubin, email address : joel.aubin@inra.fr

\begin{abstract}
:
Ecological intensification is a new concept in agriculture that addresses the double challenge of maintaining a level of production sufficient to support needs of human populations and respecting the environment in order to conserve the natural world and human quality of life. This article adapts this concept to fish farming using agroecological principles and the ecosystem services framework. The method was developed from the study of published literature and applications at four study sites chosen for their differences in production intensity: polyculture ponds in France, integrated pig and pond polyculture in Brazil, the culture of striped catfish in Indonesia and a recirculating salmon aquaculture system in France. The study of stakeholders' perceptions of ecosystem services combined with environmental assessment through Life Cycle Assessment and Emergy accounting allowed development of an assessment tool that was used as a basis for co-building evolution scenarios. From this experience, ecological intensification of aquaculture was defined as the use of ecological processes and functions to increase productivity, strengthen ecosystem services and decrease disservices. It is based on aquaecosystem and biodiversity management and the use of local and traditional knowledge. Expected consequences for farming systems consist of greater autonomy, efficiency and better integration into their surrounding territories. Ecological intensification requires territorial governance and helps improve it from a sustainable development perspective.
\end{abstract}


Keywords : agroecology, ecosystem services, emergy accounting, life cycle assessment, perception, system 


\section{Introduction}

Aquaculture context

Worldwide demand for aquatic products is growing due to population growth and increased fish consumption per capita $(+13 \%$ from 2000 to 2012$)$, and this demand is expected to increase by $57 \%$ between 2005 and 2050 (FAO 2014). As fishery catches have probably reached their maxima, this growing demand for aquatic products can only be met by aquaculture. Aquaculture production has steadily 
increased worldwide since the 1980s, and uncontrolled intensification of production in some regions has led to environmental and social problems (Troell et al. 2014). The percentage of nonfed species in the total volume of production has declined from more than $50 \%$ in 1980 to $30 \%$ in 2012 (FAO 2014), due mostly to changes in Asian cultural practices. Most Asian countries have intensified freshwater production by introducing formulated feeds into traditional production systems. Edwards (2015) highlights that the use of formulated feed is the main driver of aquaculture expansion, but it is associated with an increase in environmental damage. He suggests that aquaculture companies must consider 'realistic external costs of environmental services'. Aquaculture faces environmental challenges in its efforts to increase both quantity and quality of production without increasing negative externalities. Aquaculture depends on natural resources provided by vulnerable ecosystems (Larsson et al. 1994; Naylor et al. 2000) and may also impact biodiversity and the ecological functioning of the exploited ecosystems. Moreover, aquaculture increasingly competes with livestock and human populations for agricultural products and the land necessary to grow them, as well as with other human activities such as industry and tourism. According to Edwards, aquaculture can help use nutrients, land and freshwater more efficiently to provide human food, but the coexistence of agriculture and aquaculture requires further study (especially when there is competition between rice and fish pond systems). Several studies have been conducted to understand and assess material flows between ponds and agriculture at the regional or production-system scale, especially in Vietnam (Nhan et al. 2007; Phong et al. 2010). The high human population density in Asia, especially in Vietnam, indicates that integrating ponds and waste may be insufficient to improve regional and aquaculture system sustainability (Nhan et al. 2008). Consequently, understanding the conditions involved in integrating aquaculture-agriculture requires using specific social approaches and sometimes modelling, as shown for freshwater pond systems (Bosma et al. 2006) or coastal shrimp farming (Joffre et al. 2015).

The rapid growth of aquaculture is concomitant with warnings about the limited ability of the planet to sustain human population growth, and sustainable limits are often exceeded, resulting in biodiversity losses, climate change and disruptions in nitrogen cycling (Steffen et al. 2015).

Globally, the food system must meet growing human demand with a sustainable and steady supply of food that ensures food security for all populations, while also limiting climate change and sustaining biodiversity and ecosystem services (Foresight 2011). The role of aquaculture in the resilience of the global food system can be discussed in the light of its product diversity and reliance on feed ingredients (Troell et al. 2014). Therefore, as claimed for agriculture, it is necessary to design new aquaculture systems to increase product quantity and quality while preserving the environment and, from a sustainability perspective, considering economic robustness, development of high-quality jobs and building of new relationships among producers, consumers, and the production systems and their associated products.

\section{Principles of ecological intensification}

Since the 1930s, agriculture has been driven towards simplified intensive systems that rely upon fossil fuels and agrochemicals and produce few types of crops and cultivars. These factors have significantly increased crop yields and animal production, although they have plateaued since the 2000s (Griffon 2006). Large-scale use of agrochemicals in intensive monocultures has degraded ecosystems and decreased biodiversity. Concern initially focused on impacts of cropping systems, but livestock systems also degrade the environment, especially due to water consumption, greenhouse gas emissions and nutrient losses (FAO 2006). These impacts decrease the provision of ecosystem services and, consequently, limit potential agricultural production (Bommarco et al. 2013). Given the negative impacts of intensive agriculture, farmers and scientists have promoted new pathways for agricultural practices that are based more on ecosystem functioning and biological regulation.

The concept of ecological intensification of agriculture was developed to create new perspectives. 'Ecological intensification' seems less ambiguous and more useful for changing agriculture than 'sustainable intensification' (Petersen \& Snapp 2015), and it encompasses different ideas and viewpoints. For instance, Cassman (1999) advocates for increasing crop yields to sustain the increasing demand without causing environmental damage, while Griffon $(2010,2013)$ interprets it as intensive use of ecological functions to manage agricultural systems. The latter definition refers directly to principles of agroecology, which seeks to mimic natural processes involved in ecosystem productivity, efficiency, stability and resilience (Malézieux 2012).

Agroecology may refer to a practice, a science (Dalgaard et al. 2003) or a movement (Wezel et al. 2009). Agroecology emerged as a science in the 1930s, but was popularized by Altieri in the 1990s (Altieri 1995). Later, Altieri (2002) developed five principles especially dedicated to small-scale farming systems: (i) recycle biomass and balance nutrient flows; (ii) achieve and maintain soil conditions (e.g. organic matter, soil biotic activity) that favour plant growth; (iii) minimize losses of solar energy, air, water and nutrients (e.g. microclimate management, water harvesting, soil cover); (iv) increase species and genetic diversity in time and space and (v) increase beneficial biological 
interactions that promote key ecological processes and services. Dumont et al. (2013) adapted these principles to animal-production systems: (i) adopt management practices that improve animal health, (ii) decrease the inputs needed for production, (iii) decrease pollution by optimizing the metabolic efficiency of farming systems, (iv) increase diversity to strengthen system resilience and (v) adapt management practices to conserve biological diversity. Both sets of principles are based on two concepts: (i) recycling nutrients and energy within agroecosystems increases their efficiency (i.e. increases productivity, decreases losses and pollutant emissions) and (ii) maintaining diversity (mainly biodiversity) increases resilience, stability and robustness of agroecosystems. An agroecosystem is an ecosystem modified and managed by humans to extract resources through agriculture. This concept is complex due to the interaction between socioeconomic and ecological processes (Conway 1987; Garbach et al. 2014).

Agroecology highlights the importance of local knowledge and farmers' experience in defining adapted practices (De Schutter 2010). Participatory approaches (co-construction) facilitate adaptation of innovations to the context, increase their legitimacy and help stakeholders adopt them. Doré et al. (2011) claimed that ecological intensification requires considering additional sources of knowledge, including farmers' knowledge and knowledge of natural ecosystem functioning.

When discussing ecological intensification, several authors refer to ecosystem services. Ecosystem services are generally defined as services that natural ecosystems provide to humans, but precise definitions tend to follow two viewpoints. For some, natural ecosystems provide the ecosystem services that subsequently support agricultural production (Bommarco et al. 2013), while for others, agroecosystems themselves provide these ecosystem services (Dore et al. 2011; Griffon 2013). Thus, an agroecosystem can be considered an ecosystem, with a set of associated services and disservices (negative impacts) that it provides. The Millennium Ecosystem Assessment (2005) divides ecosystem services into four categories: proyisioning, regulation, cultural and support services. This classification highlights interactions and tradeoffs among services. Nevertheless, identification and valuation of ecosystem services remain complex and potentially controversial (Costanza et al. 2014), and using them to characterize agricultural practices may be problematic. More recently, new frameworks have been designed to update the classification of ecosystem services proposed by the Millennium Ecosystem Assessment (2005):

- The Economics of Ecosystems and Biodiversity (Sukhdev et al. 2010), a classification based on an economic approach
- Common International Classification of Ecosystem Services (Haines-Young \& Potschin 2013), which differentiates supporting and intermediate services, final services and goods and benefits

- Final Ecosystem Goods and Services - Classification System (Landers \& Nahlik 2013), which classifies ecosystem services and distinguished them from goods concept.

- Intergovernmental Science-Policy on Biodiversity and Ecosystem Services (Díaz et al. 2015), which focuses on the benefits that nature provides to humans

There is intense work on and discussion about the concept of ecosystem services and their benefits to humans, as they inverse the concept of human impacts on the environment and revise relations between humans and ecosystems.

Development of ecologically intensive agriculture has diverse consequences and generates multiple restrictions on agricultural production (Cassman 1999; Griffon 2013). Combining agroecology and ecosystem services to define ecologically intensive practices or development models entails more complex technical management of agriculture and landscape planning than in conventional agriculture. Ecologically intensive practices have to strengthen ecological solidarity among stakeholders, as has occurred in natural parks (Mathevet et al. 2010). Therefore, ecologically intensive agriculture is intensive not only in ecological functions but in knowledge, which is required to carefully manage interactions between natural ecosystems and farming systems and their uses.

Ecological intensification implies considering the vulnerability of farming systems to environmental variations (including climate change) to improve their resilience. It reinforces functions and adaptability of agroecosystems, which include the natural environment, farming systems and the territories in which they exist.

\section{Initiatives in aquaculture}

Introducing ecological principles in production-system management is not new in aquaculture. Edwards (2015) advocates revisiting traditional Asian aquaculture practices and combining them with modern practices. Bosma and Verdegem (2011) developed criteria for the ecological sustainability of pond systems, focusing first on decreasing aquaculture's inherent risks and environmental impacts, especially those on biodiversity. Direct reference to agroecology in aquaculture appears in different studies; for example, when studying changes in the use of native species in small farming systems after changing farming practices in Bangladesh (Mazumder \& Lorenzen 1999) or when studying integration of aquaculture ponds in agriculture systems in Thailand (Pant et al. 2004). 
Ecological aquaculture (Costa-Pierce 2002) 'not only brings the technical aspects of ecosystems design and ecological principles to aquaculture but also incorporates, at the outset, social ecology, planning for human community development, and concerns for the wider social, economic and environmental contexts of aquaculture' (Costa-Pierce 2010). Ecological aquaculture greatly inspired the ecosystem-based approach to aquaculture (EAA) described and promoted by the FAO (Soto et al. 2008). EAA is not considered a new approach; it is more an attempt to construct a common framework. EAA promotes greater consideration of ecosystem functions and services in productionsystem design, focuses on improving human well-being and equity and promotes greater integration of aquaculture into its economic and biophysical contexts. Soto et al. (2008) identified three main principles to guide EAA: (i) aquaculture development and management should consider the full range of ecosystem functions and services and should not hinder their sustained delivery to society; (ii) aquaculture should improve human well-being and equity for all relevant stakeholders; and (iii) aquaculture should be developed within the context of other sectors, policies and goals. One key point is not to consider the aquaculture system as a separate activity but as a part of a larger system that includes and influences the landscape. Therefore, integrating aquaculture with other human activities, mainly agriculture, is an essential factor to understand its influence on the sustainable development of a region. The EAA covers a wide range of aquaculture systems and practices at different scales. For example, in a pond system, fish yield depends directly on pond productivity, especially the natural food web. Ancient Chinese polyculture based on behaviour and trophic complementarity has endured for thousands of years. One way to intensify fish production is to strengthen the natural food web using fertilizer, organizing the species complementarity and using adapted techniques (support for periphyton, aeration, activated suspension techniques, etc.; Azim \& Little 2006). In certain Asian countries, it is relatively widespread to use plants from ponds and the surrounding environment as fish feed. For example, Black Thai fish farmers in northern Vietnam use an average of $196 \mathrm{~kg}$ of fresh leaves day ${ }^{-1} \mathrm{ha}^{-1}$ in their polyculture ponds (Pucher et al. 2013), and on the island of Java (Indonesia) feeding giant taro (Alocasia macrorrhizos) leaves to giant gourami fish (Osphronemus goramy) is an ancient practice (Huet 1956) that largely still occurs today. Floating aquatic macrophytes may also help to improve aquaculture system productivity (by producing fish feed and improving water quality). Their use has been studied in experimental and field trials in many Asian countries (see Hasan and Chakrabarti (2009) for a review). Other floating plants, such as Azolla sp. and some duckweed genera (Lemna, Wolfia, Wolfiella and Spirodela), have nutritional value for fish and in certain conditions can provide other beneficial ecological properties and ecosystem services (Tsuruta et al. 2011; Zhao et al. 2014).

Recirculating aquaculture systems provide new perspectives for water resource use, in feed efficiency and water-quality monitoring and may contribute to influence sustainable development of aquaculture (Martins et al. 2010). This system could evolve due to the technical improvements in the water treatment loop and through the integration of species from different multiple trophic levels for the recycling of nutrients. These developments could therefore approach ecological aquaculture concepts.

The development of sustainable aquaculture schemes plans is not straightforward. Considering the three dimensions (i.e. social, economic and environmental) does not help to propose practical objectiyes and their declination in technical or organizational arrangements. Different codes of conducts were produced and helped to fish farmer awareness and to the application of responsible practices (Boyd 2003). Nevertheless, the standards development sometimes failed to improve sustainability (Belton et al. 2009).

\section{Rationale of the study}

Given the challenges facing aquaculture, which combine the objectives of increased production and environmental conservation, it appears particularly relevant to adapt the concept of ecological intensification and to define pathways that will allow stakeholders, including fish farmers, to endorse the concept and put the guidelines into practice.

Therefore, a group of scientists from aquaculture, aquatic ecology and social sciences launched a multidisciplinary project to adapt ecological intensification to aquaculture, develop and test a method to implement it in aquaculture and define principles and pathways to implement it. To reach these objectives, ecological intensification was adapted based on agroecological principles and the ecosystem service framework. The multidisciplinary approach involved stakeholders (e.g. fish farmers, members of the value chain, local inhabitants, regional managers) from different study sites to co-design ecologically intensive farming systems adapted to different contexts. The study sites (France, Brazil and Indonesia) benefit from a wide range of perspectives due to the economic and biophysical diversity associated with their differing models of aquacultural development.

\section{Materials and methods}

\section{Case studies}

The case studies (Table 1) were chosen to cover a wide range of situations, from extensive to intensive aquaculture and different social and cultural environments. They were 
Table 1 Main characteristics of the refers production systems studied

\begin{tabular}{|c|c|c|c|c|}
\hline System & Main issues & Input use & Yields & Assumed initial diversity of ecosystem services \\
\hline Extensive ponds in Lorraine and Brenne (France) & $\begin{array}{l}\text { Profitability } \\
\text { Environment }\end{array}$ & Very low & Very low & High \\
\hline Integrated pig - pond system in Santa Catarina (Brazil) & Regulation & Low & High & Medium \\
\hline Intensive striped catfish pond (Indonesia) & Profitability & Very high & Very high & Low \\
\hline Salmon recirculating aquaculture system (France) & Environment & Very high & Very high & Low \\
\hline
\end{tabular}

characterized according to the representativeness of their specific aquacultural issues, the amounts of inputs (especially feed) they used, the productivity per ha, the expected variety of ecosystem services provided by the aquaecosystem and local and scientific partnership. They are presented in a gradient from the least to most intensive.

Large pond farms (from 1 ha to several hundred ha) in Lorraine and Brenne (France) are devoted to the polyculture of cyprinids; the main species are common carp (Cyprinus carpio), roach (Rutilus rutilus), rudd (Scardinius erythrophthalmus), tench (Tinca tinca) and predators such as pike (Esox lucius) and European perch (Perca fluviatilis). The production system is fed mainly natural autotrophic biomass (primary production), generally sustained by nutrients from watersheds and sometimes additional fertilizer. Formulated feeds or cereals may be used during part of the cycle, mainly as nutritional supplements. Although fish yields are low, ranging to 50 $300 \mathrm{~kg} \mathrm{ha}^{-1}$ year $^{-1}$, pond farming is considered a patrimonial activity that supports a specific biodiversity of habitats and species (especially birds, amphibians, insects and aquatic plants), forms part of the landscape and regional wildlife parks (Parcs Naturels Régionaux de Brenne et Lorraine, Ramsar Convention of Wetland sites, Habitats Directive of the European Union) and supports recreational activities. Due a decrease in the fish restocking market, the low profitability of aquaculture has led to progressive abandonment of pond farming in favour of managing pond areas for hunting, leisure activities or nature conservation; this has led to the natural closing of vegetation which decreases biodiversity in ponds and surrounding wetlands. Moreover, the environmental impacts of ponds, especially when drained, are controversial (Banas et al. 2008).

Integrated pig and fish production was studied in Santa Catarina state in Brazil. Production is based on a polyculture developed in the 1990s to optimize the food web, using common carp and/or Nile tilapia (Oreochromis niloticus) as the main species, combined with herbivorous carp (Ctenopharyngodon idella), phytoplanktivorous silver carp (Hypophthalmichthys molitrix) and zooplanktivorous bighead carp (Hypophthalmichthys nobilis). Pigsties are installed over the ponds, and the pig manure sustains pond productivity according to two different systems. The first one, MOCAPI, uses only pig manure as a nutrient source and includes a variety of local fish species: jundiá (Rhamdia quelen), cascudo (Hypostomus sp.) and pacu (Piaractus mesopotamicus). This system produces 4-6 t of fish $\mathrm{ha}^{-1}$ year $^{-1}$ (Casaca et al. 2005). The second one, MAVIPI, is more intensive because, along with pig manure, formulated feed is added and a surface aerator is used to homogenize the water nutrient concentration and increase the dissolved oxygen concentration when fish growth rate plateaus. Fish yields can reach $10-12 \mathrm{tha}^{-1}$ year ${ }^{-1}$. The quality of effluent outlet water from these two systems is controversial, and enyironmental regulation is about to ban these systems from the vicinity of rivers, which threatens their future development.

In the district of Muara Jambi in Sumatra, Indonesia, triped catfish (Pangasianodon hypophthalmus) is produced in an intensive monoculture in earthen ponds. This system was initially developed to diversify agricultural production after an economic crisis in the 1990s, when pineapple production, the only crop adapted to the site's acidic soils, was in jeopardy. This system has expanded considerably in the district over the past 10 years, and more than 4,000 ponds now exist. The small earthen ponds $(\approx 0.3 \mathrm{ha})$ are fed mainly by the water table. Fingerlings with a mean weight of $5 \mathrm{~g}$ are stocked in the pond at a mean density of 15 individuals per $\mathrm{m}^{2}$ for a growing cycle of 6 months. Fish are fed ad libitum twice a day with crumb feed (36-40\% protein) during the first 2 weeks of rearing and then receive a pelleted feed with gradually increasing diameter and decreasing protein content. Mean fish production is $76 \mathrm{t} \mathrm{ha}^{-1}$ cycle $^{-1}$ (i.e. $152 \mathrm{t} \mathrm{ha}^{-1}$ year $^{-1}$ ), with a feed conversion ratio of 1.5-2.2 depending on feed composition and feeding practices. Fish feed is commercial or homemade, in which case it is based on trash-fish meal and agricultural coproducts (e.g. rice bran and middling, cotton meal). After a period of intense development, the price of striped catfish decreased, while the price of feeds and feedingredients increased; this greatly decreased profitability and thus threatened the economic viability of the system.

A salmon (Salmo salar) recirculating aquaculture system (RAS) is located on the shore of the Basse-Normandy region (western France) in a natural park (Parc Naturel Régional des Marais du Cotentin et du Bessin, Ramsar site). The farm uses brackish groundwater pumped from a depth 
of $15 \mathrm{~m}$ (water temperature ranges from $10^{\circ} \mathrm{C}$ in winter to $16^{\circ} \mathrm{C}$ in summer and salinity is $25 \%$ ) and filtered to decrease iron concentration to $0.01 \mathrm{mg} \mathrm{L}^{-1}$. The RAS is composed of separate production units that include a rearing tank equipped with its own water treatment loop to extract solids, nitrify dissolved ammonia (with mechanical and biological filters) and maintain acceptable oxygen and carbon dioxide concentrations. Fish are fed formulated feed with a high percentage of fish-based ingredients (77\% fish meal and oil, and no vegetable oil, for optimal flavour), and water velocity in the tank is kept at $\approx 25 \mathrm{~cm} \mathrm{~s}^{-1}$ to optimize fish welfare through swimming. Final fish density is $\approx 100 \mathrm{~kg} \mathrm{~m}^{-3}$, and salmon are sold in high-quality niche markets. Total fish production was $50 \mathrm{t} \mathrm{year}^{-1}$ (from 2010 to 2014) and reached $150 \mathrm{t}$ in 2015 . The quantity of inlet water is about $1 \mathrm{~m}^{3}$ per $\mathrm{kg}$ feed, and the sludge is used as organic fertilizer for nearby crops. Nevertheless, emissions of dissolved nitrogen and phosphorus are an issue, especially for shellfish farmers downstream in the bay. Interactions with local people are few because the fish farm is very private. This production system has high energetic efficiency (Wilfart et al. 2013).

\section{Conception loop}

We defined a conception loop based on a multidisciplinary approach. We conceived (i) a representation of aquaecosystems that illustrates the state of ecological intensification, (ii) a definition of ecological intensification specific to aquaculture, (iii) defined pathways to ecologically intensive aquaculture and (iv) principles to stimulate the emergence of new fish farms. The steps of this loop (Fig. 1) include (i) assessment of a study site (i.e. aquaecosystem typology, analysis of the perception of ecosystem services, environmental assessment), which defines the initial state of ecological intensification; (ii) co-design of improvement scenarios; (iii) co-design and conducting of experiments; (iv) analysis of experimental results; (v) adaptation of scenarios to define; and (vi) recommendations, principles and pathways. See the guide of Aubin et al. (2014) for more detailed description of the steps of this loop.

\section{Defining aquaecosystem types}

As performed for agroecosystems, we defined an aquaecosystem as a human-managed aquatic ecosystem oriented towards the provision of ecosystem services, including provisioning services (Fig. 2). The aquaecosystem is described as an integration of subsystems: the farming system, the territory, 'resource ecosystems' and 'receiving ecosystems'. Resource ecosystems are the ecosystems affected by, or involved in, the inputs supplied to the farming system. These include support ecosystems that produce feed ingredients, such as terrestrial agroecosystems for crop ingredients or marine ecosystems for fish meal and oil. Downstream, the same concept can be used for receiving ecosystems, which are the locations where aquaecosystem services and disservices are expressed. The connected aquaecosystem can be affected by outflow water from the farming system, but distant ecosystems can also be affected, such as those in which migrating species (e.g. birds) spend

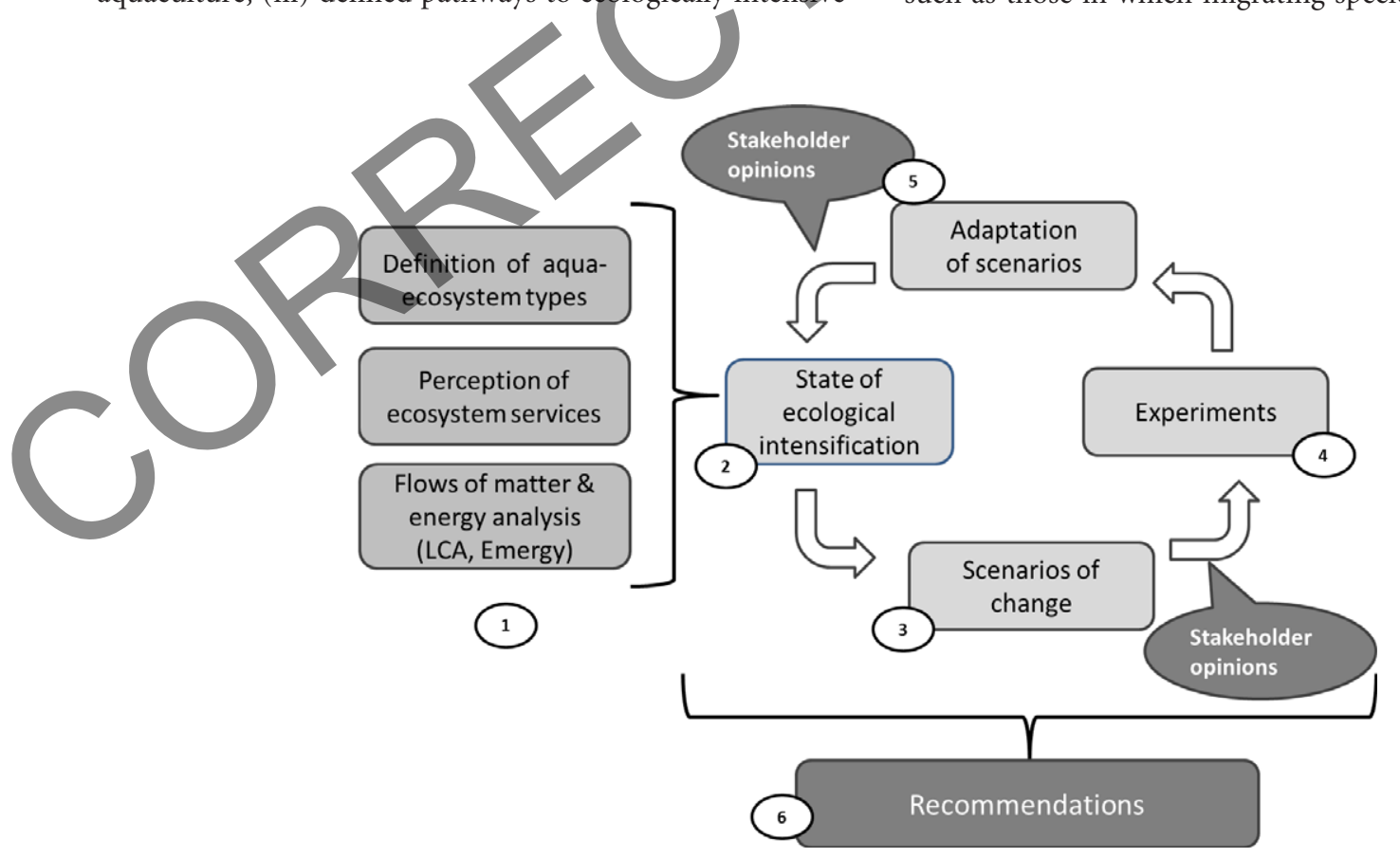

Figure 1 Conception loop for ecological intensification of aquaculture. 
part of their life cycle or those that receive fish for restocking. The concept of receiving ecosystem can be extended to the social system that uses products (provisioning service) from the farming system (consumers). In the aquaecosystem, a territory is defined as a continuous area or neighbouring landscape units with a set of soil and climate conditions and a system of governance. A territory is where interactions and coordination with other human activities occur. In some cases, a territory can be confused with receiving and resource ecosystems, as the same territory can support production of resources and receive services and disservices from farming systems. In other cases, both the territory and the receiving or resource ecosystems can overlap for certain management flows or be clearly disconnected. The farming system is where farmers' management activities occur. It supports fulfilment of production objectives through rearing practices, which are influenced by regulations (economic, environmental and social) imposed on the farming system.

\section{Assessing ecological intensification}

As defined above, ecological intensification is based on principles of agroecology and ecosystems services. Altieri and Toledo (2011) underlined that agroecologic systems are systems relied on local innovation, resources and solar energy and far away from fossil fuel-based production. Therefore, ecological intensification was assessed using social and biophysical approaches.

Social approach. As no generic list of ecosystem services specific to fish farming was available, the list from the Millennium Ecosystem Assessment (2005) was adapted to fish farming, based on the literature and multidisciplinary knowledge, to provide a reference list for the subsequent surveys. The complete list contains 28 ecosystem services (Table 2). To assess local knowledge and perceptions of ecosystem services, farmers and other stakeholders (Table S1) were interviewed using semi-structured questionnaires (Blayac et al. 2014; Mathé \& Rey-Valette 2015).

Understanding perceptions of ecosystem services requires precise survey protocols (Kaplowitz 2000; Kaplowitz \& Hoehn 2001; Kumar \& Kumar 2008; Quétier et al. 2010). Therefore, our questionnaire combined closed-ended (ranking along a scale (Duc 2008)) and open-ended questions (spontaneous perceptions). The open-ended questions, placed at the beginning of the questionnaire, helped identify perceptions without mentioning the concept of ecosystem services. Interviewees were then asked to rank the 10 seryices they valued most from the reference list. Unlike the openended questions, the list suggested services that may not have spontaneously come to mind. As well as the perception of services, multiple structural and functional characteristics of fish farms were also studied, as in previous studies assessing aquaculture sustainability (Lazard et al. 2009).

Services were assigned to three categories based on the value of natural capital developed by Petrosillo et al. (2013): (i) economic value, related to economic opportunities generated by the aquaculture system; (ii) biological value, related to supporting and regulation services; and (iii) cultural value, related to heritage and recreational services. A comparison method was used to analyse the percentage of services mentioned by farmers and other stakeholders (frequency of citations related to the number of individuals interviewed). To quantify the services valued

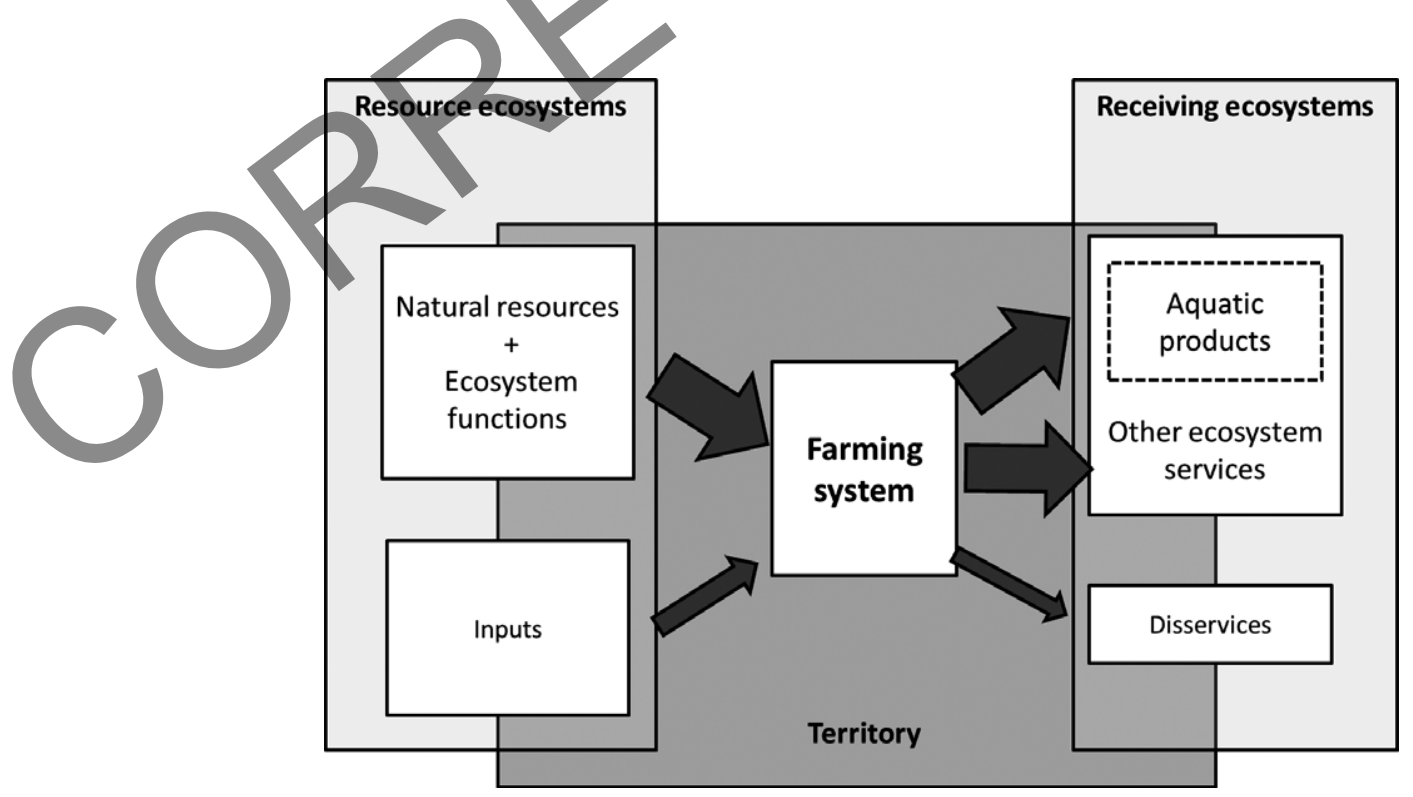

Figure 2 Aquaecosystem components involved in ecological intensification. Adapted from Griffon (2013). 
Table 2 Major ecosystem services adapted to aquaecosystems

Ecosystem services

Provisioning

- Production of fish

- Production of fibre

- Production of medicines

- Production of fertilizers

- Freshwater reservoir

- Provision of combustible materials
Regulation

- Climate regulation

- Hydrological regulation

- Retention and decontamination of pollutants

- Protection from fire

- Protection from floods

- Protection from diseases most among the three countries, we calculated the percentage of individuals who mentioned each service out of the total number of individuals interviewed for each site.

Biophysical approach. Material flows associated with the production systems were analysed using Life Cycle Assessment (LCA) applied to aquaculture (Pelletier et al. 2007; Pelletier \& Tyedmers 2008; Henriksson et al. 2011; Aubin 2013) and using Emergy accounting (Wilfart et al. 2012a, 2013). LCA is a standardized method (ISO 2006a,b) to assess potential impacts associated with producing a product; it estimates resources consumption and emissions into the environment at all stages of its life cycle, from raw material extraction to its end of life (Guinée et al. 2002). LCA was performed using two functional units: one ton of fish and one ha of on-farm water. The LCA potential impact categories selected for this study are traditionally used in LCA of aquatic products (Pelletier et al. 2007). Eutrophication, acidification, climate change, land competition and water dependence originate from the CML2 Baseline 2000 method (Guinée et al. 2002). Net primary production use is defined by Papatryphon et al. (2004), and total cumulative energy demand is calculated according to Frischknecht et al. (2004).

Emergy is the amount of energy (in solar-energy equivalents) that is directly or indirectly required to provide a given flow or storage of energy or matter (Odum \& Peterson 1996). Emergy accounting provides indicators to estimate energy quality and efficiency throughout the life cycle. Tables S2 and S3 in the supporting information provide details about Emergy indicators. These two approaches were chosen because they are complementary and reflect links between the farming system and the aquaecosystem. Moreover, environmental impacts reflect the amounts of inputs used and the amounts and fates of matter leaving the farming system. They are compatible because their inventory stages (i.e. data collection) can be conducted simultaneously (Wilfart et al. 2013). LCA and Emergy accounting were performed for a sample of farms at each study site: 30 polyculture farms in France, 20 integrated polyculture farms in Brazil, 15 striped catfish farms in Indonesia and 1 salmon RAS in France. We developed a tool called PISC'n'TOOL to standardize inventories and indicator calculations (Wilfart et al. 2012b). It considers variability in practices and environmental performances in aquaculture systems (Aubin et al. 2015). Social implications of aquaculture systems were studied using social LCA (Mathé 2014) and innovation capacity analysis (results not shown).

\section{Constructing and testing scenarios}

Scenarios were constructed and tested in multiple steps, from design, to experimentation, to evaluation. Using the survey and assessment information, along with specific data about the production context, the state of ecological intensification was assessed for each case study. LCA and Emergy accounting results were included in this stage as they identified hotspots in the systems and main contributors to environmental impacts. In parallel, the ecosystem services hierarchy helped define stakeholders' needs from and expectations about aquaculture systems at each site. General guidelines were established for each production system, which included elements of the assessment and principles of ecological intensification in aquaculture (Fig. 1). The stakeholders prioritized the guidelines within working groups, and scenarios for possible evolution were designed using procedures adapted to each case study. Some evolution scenarios were co-constructed with stakeholders, while others were proposed by scientists and then discussed and adapted by stakeholders. 
Experiments were designed and performed after constructing the scenarios. In certain case studies, experiments were performed directly on fish farms along with fish farmers, while in others they were performed in experimental facilities. The experiments were performed over 1-2 production cycles. Results of the experiments were shared with project partners, farmers and other stakeholders of each case study. Degrees to which the concepts and technical applications were adopted varied.

To present assessment results using a qualitative scale, we divided them into five classes (A, B, C, D, E) with $20 \%$ relative value each, using the highest value observed for each indicator among all sites and fish farms as $100 \%$. 'A' represents the $20 \%$ most favourable situations (i.e. lowest negative impacts), and ' $E$ ' represents the 20\% least favourable situations.

\section{Results}

\section{Elements of assessment}

Environmental assessment: consumption from resource ecosystems and emissions to receiving ecosystems

Performance profiles of the systems varied greatly among indicators and functional units (Table 3 and Table S4).
The extensive pond system in France showed a contrasting profile. For LCA indicators per ton of fish, performance was low (class E), especially for input use (i.e. land, water, anthropogenic energy use), due to its low productivity $\left(\approx 300 \mathrm{~kg} \mathrm{ha}^{-1}\right.$ year $\left.^{-1}\right)$. Conversely, for LCA indicators per ha, all impact categories lay in the best class (A) except for land competition (C), which had a low performance. According to Emergy indicators, this system, based on natural productivity, used renewable energy inputs well, depended less on the economic sphere and had a good performance in \% of renewability (A) and the best Emergy sustainability index (A). Nevertheless, its ability to transform overall energy (Transformity) was low.

The integrated pig and fish pond system in Brazil had more balanced results among methods and functional units. It had relatively low environmental impacts according to LCA indicators per ton of fish or per ha for climate change (B/A), energy use (A) and net primary production (NPP) use (A). This profile indicated generally good efficiency in input use, but with a risk of nutrient emissions, indicated by high eutrophication (E) and acidification (E) per ton of fish. For LCA indicators per ha, the high land competition (E) demonstrated the dependence of pig and fish feed on plant-based ingredients. Its overall good performance among Emergy indicators revealed high efficiency

Table 3 Mean qualitative ranking of the study systems according to LCA indicators per ton of fish, LCA indicators per ha of on-farm water area and Emergy accounting ratios. Letters represent mean values converted into five classes (A, B, C, D and E) with 20\% relative value each, using the highest value observed for each indicator among all sites and fish farms as 100\%. 'Extensive pond Fr.' refers to extensive ponds in Lorraine and Brenne (France); 'Integrated pig-pond Br.' refers to integrated pig-pond system in Santa Catarina (Brazil); 'Int. striped catfish Ind.' refers to intensive striped catfish ponds in Sumatra (Indonesia); 'Salmon RAS Fr.' refers to a salmon Recirculating Aquaculture System (France)

\begin{tabular}{|c|c|c|c|c|}
\hline Method/indicator & $\theta$ & Integrated pig-pond $\mathrm{Br}$. & Int. striped catfish Ind. & Salmon RAS Fr \\
\hline \multicolumn{5}{|l|}{ LCA per ton of fish } \\
\hline Acidification & & E & $\mathrm{D}$ & C \\
\hline Eutrophication & & E & C & $E$ \\
\hline Climate change & & B & A & E \\
\hline Tot. cum. energy c & E & A & A & E \\
\hline Net primary production use & A & $A$ & A & $E$ \\
\hline Land competition & E & A & A & A \\
\hline Water dependence & E & B & A & A \\
\hline Acidification & A & B & E & C \\
\hline Eutrophication & A & B & $\mathrm{D}$ & $E$ \\
\hline Climate change & A & A & B & E \\
\hline Tot. cum. energy demand & A & A & A & E \\
\hline Net primary production use & A & A & A & E \\
\hline Land competition & C & $E$ & $E$ & E \\
\hline Water dependence & A & $E$ & C & $\mathrm{D}$ \\
\hline \multicolumn{5}{|l|}{ Emergy accounting } \\
\hline Transformity & $E$ & C & A & $\mathrm{E}$ \\
\hline$\%$ Renewability & A & A & C & C \\
\hline Emergy yield ratio & A & A & A & A \\
\hline Emergy investment ratio & B & C & $E$ & $\mathrm{D}$ \\
\hline Environ. loading ratio & B & C & E & $E$ \\
\hline Emergy index of sustainability & A & B & D & D \\
\hline
\end{tabular}


in energy use, especially in renewable sources (A), and therefore a good level (B) of sustainability.

The intensive striped catfish pond system in Indonesia had low environmental impacts (class A) for LCA indicators per ton of fish, especially for climate change, energy use, NPP use, land competition and water dependence. This performance was not observed when calculating LCA indicators per ha (except for energy use and NPP use, which remained in class A). This was because the high productivity $\left(\approx 40 \mathrm{t} \mathrm{ha}^{-1}\right.$ year $^{-1}$ ) increased nutrient emissions per ha (class E for acidification, class D for eutrophication). Among Emergy indicators, its high dependence on nonrenewable energy sources induced low performance (E) in the Emergy investment ratio and the environmental loading ratio and a low Emergy sustainability index (D); however, the system was able to transform efficiently the different forms of energy in fish, as shown by its Transformity (A).

The salmon RAS in France had relatively high environmental impacts (class E) in LCA indicators per ton of fish and per ha for eutrophication, climate change, energy use and NPP use. This profile was due to high productivity (lower than that for striped catfish ponds, however) combined with a high dependence on purchased energy and on fish oil and meal in fish feed. Potential eutrophication was high (class E), despite internal water treatment. The need for plant-based ingredients in fish feed induced high land competition per ha $(E)$, which was the opposite of its good ranking (A) when calculated per ton. LCA indicators agreed with the Emergy indicators, which indicated dependence on nonrenewable energy through the Emergy investment ratio (D) and the environmentalloading ratio (E). The system's Transformity (E) and Emergy sustainability index (D) were low, as they were for the striped catfish system.

Perception of services: services provided to the receiving ecosystem

Perceptions of provisioning services provided to the receiving ecosystem tended to concentrate on a few components (fish, freshwater and plants) among systems (Table 4; Figs S1-S3). Perceptions about regulation support and cultural services were more diverse. For extensive polyculture ponds in France, biodiversity and the natural quality of the aquaecosystem were perceived as important. Perceptions of services were similar for the integrated pig and pond system in Brazil, with particular focus on hydrological characteristics. For striped catfish ponds in Indonesia, perceptions were the most diverse, with a wider variety of provisioning services and a great focus on shared knowledge. The salmon RAS system in France had the fewest perceived services, perhaps because of its disconnect with the local environment (indoor system). Its high recognition of heritage was an artefact of the highly developed oyster production systems in this region, which certain stakeholders associated with aquaculture. Additional details of stakeholder perceptions can be found in Mathé and Rey-Valette (2015).

\section{Developing and testing ecological intensification scenarios}

For the extensive pond system in France, stakeholders defined five general objectives for ecological intensification scenarios:

1 Better define the ecological values of ponds and their purification capacity. Expected application relies on better identification and assessment of support (biodiversity support, nutrient cycling) and regulation (purification, hydrology) ecosystem services, which may lead to new regulations and payment for services (e.g. water purification at the watershed level (Gaillard et al. 2015)). This objective is supported by the good performances in eutrophication and water dependence when LCA is calculated per ha.

2 Develop combined farming systems by associating a small intensive (or semi-intensive) productive area (in cages, net pens, etc.), in which fish species with economic value (carnivorous fish such as pike-perch) receive formulated feeds, and a large extensive area to improve the quality of water from the intensive area, while supporting extensive polyculture and aquatic biodiversity. The main objective of this system is to combine provisioning services and support services. This is in line with the observed differences in environmental performances when LCA is calculated by ha or by ton of fish, showing the low productivity of the system.

3 Better take advantage of the trophic web, especially phytoplankton and periphyton, using fish species of low trophic level in polycultures. The objective is to increase system efficiency through cultured biodiversity.

4 Increase the use of 'natural' nutrients from watersheds and pond sludge. Pond management (i.e. use of lime and drying periods to mineralize pond sludge) and the choice of species reared in a polyculture can increase nutrient recycling and decrease dependence on external inputs. This objective has the potential to improve the EIR and the energy demand by ton of fish produced.

5 Strengthen the ecological and hunting values of ponds. One objective of fish farmers is to adapt practices to manage trade-offs between fish farming and hunting, the two sources of income, while developing the natural value of fish ponds.

In Brazil, the integrated fish pond and pig system is in itself an agroecological system. Two possibilities were explored to strengthen its orientation towards ecological intensification. The first uses outlet water from the ponds to irrigate onions and creates a treatment channel to produce floating plants (Eichhornia crassipes or 
Table 4 Mean qualitative ranking of farmers' and other stakeholders' perceptions of ecosystem services provided by aquaculture systems at the study sites. Letters represent mean values converted into five classes ( $A, B, C, D$ and E) with $20 \%$ relative value each, using the highest value observed for each indicator among all sites and fish farms as 100\%. 'Extensive pond Fr.' refers to extensive ponds in Lorraine and Brenne (France); 'Integrated pig-pond Br.' refers to integrated pig-pond system in Santa Catarina (Brazil); 'Int. striped catfish Ind.' refers to intensive striped catfish ponds in Sumatra (Indonesia); 'Salmon RAS Fr.' refers to a salmon Recirculating Aquaculture System (France). '-' indicates that the service was not selected

\begin{tabular}{|c|c|c|c|c|}
\hline & $\begin{array}{l}\text { Extensive } \\
\text { pond Fr. }\end{array}$ & $\begin{array}{l}\text { Integrated } \\
\text { pig-pond Br. }\end{array}$ & $\begin{array}{l}\text { Int. striped } \\
\text { catfish Ind. }\end{array}$ & $\begin{array}{l}\text { Salmon } \\
\text { RAS Fr. }\end{array}$ \\
\hline \multicolumn{5}{|c|}{ Provisioning services } \\
\hline Fish & A & $A$ & A & A \\
\hline Plants & $\mathrm{E}$ & $\mathrm{E}$ & $B$ & $\mathrm{D}$ \\
\hline Freshwater & $\mathrm{D}$ & $B$ & B & - \\
\hline Fibre & - & - & E & - \\
\hline Energy source & E & - & $E$ & - \\
\hline Ornamental & E & E & $\mathrm{D}$ & - \\
\hline Medicines & E & - & C & - \\
\hline Fertilizer & E & $E$ & $\mathrm{C}$ & $\mathrm{D}$ \\
\hline \multicolumn{5}{|c|}{ Regulation and support services } \\
\hline Local Climate & $\mathrm{D}$ & C & $\mathrm{D}$ & - \\
\hline Hydrology & C & B & C & - \\
\hline Storms & $\mathrm{D}$ & $\mathrm{E}$ & $\mathrm{D}$ & - \\
\hline Depollution & C & C & $\mathrm{D}$ & - \\
\hline Illness & $C$ & $E$ & $D$ & - \\
\hline Biodiversity & A & B & $D$ & E \\
\hline Plankton & D & B & $E$ & \\
\hline Refuge & B & $\mathrm{E}$ & $\mathrm{E}$ & E \\
\hline Reproduction & $C$ & $\mathrm{D}$ & $E$ & E \\
\hline Nutrients & $D$ & $\mathrm{D}$ & $\mathrm{D}$ & c \\
\hline Soils & $E$ & $E$ & $D$ & - \\
\hline Wetlands & C & $\mathrm{D}$ & D & \\
\hline \multicolumn{5}{|l|}{ Cultural services } \\
\hline Heritage & C & & D & $A^{*}$ \\
\hline Inspiration & D & & & - \\
\hline Know-how & & & B & $D$ \\
\hline Awareness & & & C & C \\
\hline Landscape & & & C & - \\
\hline Fishing/Hunting & $z$ & $F$ & E & - \\
\hline Tourism & $D$ & D & $D$ & D \\
\hline Leisure & D & C & $C$ & - \\
\hline
\end{tabular}

Pistia stratiotes) that could be composted to fertilize agricultural crops. This solution would help improve the territorial integration and acceptance of the production systems and improve management of waste nutrients. It would also improve eutrophication level in LCA and ELR. The second possibility entails reducing the use of feed in the MAVIPI system by decreasing the number of feeding days to optimize nutrient recycling in ponds and decrease dependence on external inputs. Presenting ecosystem services as a framework to identify roles of the aquaecosystem helped the farmers' organization defend the legitimacy of the production systems in their territories.

In Indonesia, the scenario was designed with extension services and the farmers' organization, based on local knowledge. A variety of species and systems are available, and the suggested scenario combined solutions and practices. Monoculture of striped catfish evolved into a system in which catfish are reared and fed in cages in the centre of traditional ponds, while the surroundings are seeded with duckweed (which feeds extensive production of giant gourami a mostly herbivorous fish, reared in the same pond). This scenario, based on nutrient recycling and water quality management, diversifies the species produced. Overall efficiency of the system is improved by better managing striped catfish production and coproducing giant gourami. Moreover, the nutrient content of outflow water is a useful source of fertilizer for surrounding paddy fields, palm trees and market gardens. This new production system has a better performance in eutrophication and acidification calculated by LCA and improve \% of renewability in Emergy accounting.

For the salmon RAS in France, interviews were conducted mainly with the owner and the farm's technical manager. Two main ideas inspired the design of the scenario. As it is a highly technical and efficient transformation system based on a large quantity of inputs, designing a new system appeared particularly difficult. Therefore, it was decided to improve its environmental performance in two ways: (1) produce algae (Ulva sp.), which would absorb dissolved waste nutrients, as a potential source of additional income and (2) create a wetland to improve the quality of outlet water and support biodiversity. Combining these two solutions should improve the overall nutrient-use efficiency of the system and improve its natural image, while decreasing pollutant emissions. They have the potential to decrease eutrophication potential, a major concern of this system as shown by LCA.

\section{Discussion}

Definition of ecological intensification of aquaculture The principles of agroecology, ecosystem services and ecological intensification described in the literature were compared to the field experiments and representation of aquaecosystems, which helped define ecological intensification of aquaculture. Ecological intensification of aquaculture is based on using ecological processes and functions to increase productivity, strengthen ecosystem services and decrease disservices. It is based on biodiversity management and local and traditional knowledge. Expected consequences are an increase in farming system autonomy and efficiency and an improvement in their integration into territories. Ecological intensification requires and contributes 


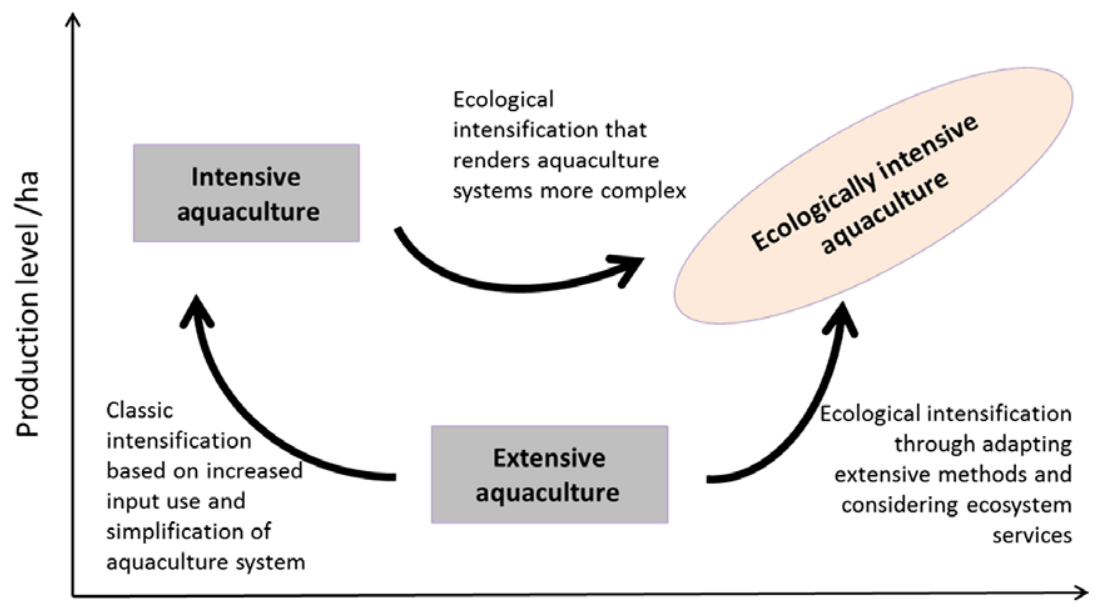

Number of ecosystem services

Figure 3 Pathways to ecological intensification of aquaculture and classic intensification.

to improving territorial governance from a sustainable development perspective.

Ecological intensification follows different pathways, which increases system complexity and requires considering ecosystem services. These pathways differ from classic intensification based on system simplification and increased input use, which is generally associated with a decrease in ecosystem services (Fig. 3). In classic intensification, simplifying the system initially affects the species assemblage and nutrient cycles. The transition towards ecological intensification is not always associated with a decrease in labour (often desired in classic intensification), especially when changing from a conventional extensive system to fed aquaculture (time for feeding, supply management, etc.). Considering the variety of objectives and limitations associated with the ecological intensification of aquaculture (e.g. technical, biological, physical, social, economic), we developed seven principles that can guide the transition.

Seven principles to guide ecological intensification of aquaculture

The principles, presented in no particular order, describe concepts for defining ecological intensification of aquaculture, details of the definition presented previously and practices and recommendations to help implement it.

\section{Minimize dependence on resource ecosystems}

This principle relates directly to promoting more autonomous systems less dependent on chemical inputs or, more generally, on the techno-sphere, as proposed by Altieri (2002) and Bommarco et al. (2013). This principle is not only adapted to small self-sufficient systems, but is the choice of decreasing dependence on a variety of economic resources and key unsustainable resources, such as fossil fuel or fish meal and oil (Tacon et al. 2010). In particular, it promotes the use of renewable resources such as solar energy through photosynthesis and the nutrient sources available in watersheds or stocked in soils and sludge. The principle does not recommend any associated practices, which can range from substituting resources to changing production objectives (e.g. abandoning monoculture for polyculture to use natural biomass better or increase input efficiency). The role of plants (including phytoplankton and algae) is central as they can be a direct or indirect source of nutrients for reared species. Biological mechanisms are favoured because they can replace chemical or physical inputs, or interact favourably with them and play the same agronomic role without external costs, particularly environmental costs (Doré et al. 2011).

Increase performance of farming systems and quality of aquatic products

Aquaculture production needs to expand to meet the increasing demand for aquatic products. Ecological intensification suggests an increased level of production (Griffon 2010). It is necessary to increase a system's overall efficiency using a range of practices, either by decreasing inputs per unit produced or by increasing production per unit input. In particular, feed efficiency must increase, as it is the main mechanism for decreasing environmental impacts, as revealed by LCA (Aubin et al. 2009). The system's economic efficiency is also crucial, and the return on investment while changing the production system may create an obstacle. Designing a system able to provide products of sufficient quality to meet market demand is challenging, especially for systems based on ecological functions, which are more sensitive to climatic and environmental 
fluctuations. Better performance may also mean improving a product's image, which could increase its value due to the use of more acceptable practices, as in organic production.

Improve robustness, flexibility and resilience of farming systems via integration and functional complementarity

This principle is based on the role of diversity, especially biodiversity in the production system. Biodiversity is considered a key factor in agroecosystems' abilities to resist environmental or pathological crises (robustness), to recover after such a crisis (resilience) and to adapt to a change in the context (flexibility; Altieri 1999). A parallel can be drawn in the economic domain, in which diversified production can help a system survive economic crises by balancing market risks. Therefore, the aim is to develop aquaculture systems based on the complementarity of functions provided by diverse target species and nontarget species. This is specifically the case in polyculture systems based on the trophic complementarity of species and integrated multitrophic aquaculture (Troell et al. 2009). It is similar to the integration of other aquatic or land-based production, such as crops or livestock. The desired ecological functions are not limited to trophic ones, such as habitat competition, chemical emissions and purification, as many ecological functions are complementary and contribute to the productivity and stability of aquaecosystems. Plants are therefore a key compartment as they cover a wide range of functions such as habitat for targeted or nontargeted species (i.e. reed belt in pond systems), depuration by their role in $\mathrm{C}$, $\mathrm{N}, \mathrm{P}$ cycling and also trophic as a soulce of feed for different species. Diversify the market-oriented ecosystem services of aquacul-
ture systems

Including ecosystem services in the design of aquaculture systems is an opportunity to increase public awareness of their benefits and to diversify a farm's income sources. This contributes to changing the community's perception of the practice. Concerning provisioning services, an economic use can be considered for coproducts such as fertilizers (sludge) and aquatic plants, which can contribute to the economic robustness of the fish farm. Cultural services can be considered using the aquaecosystem as a support for specific knowledge (e.g. culinary traditions, environmental education) or for recreational activities such as hunting, angling or nature excursions (e.g. bird watching). Creating economic value for these types of services generally entails investments in time and money and changes in work organization. They may also require negotiating trade-offs between provisioning and cultural services, for instance, selecting dates for pond drying that do not adversely affect fishing and hunting.
Promote awareness of services and better use of skills and know-how

Ecological intensification implies the participation of different stakeholders. Recognition of ecosystem services depends on stakeholders' perceptions. Therefore, specific formal or informal measures must be implemented to reach a compromise among the stakeholders. This information will help orient the production system to match the environmental, social and economic context of the territory. Moreover, the skills and know-how directly or indirectly part of the aquaecosystem are a source of inspiration for developing ecological intensification practices. Using them when designing a new system can contribute to the adoption and dissemination of practices.

Improve territorial integration of aquaculture systems by promoting production of nonmarket ecosystem services

Identification of nonmarket ecosystem services is another key point in developing ecological intensification of aquaculture. It is essential to broaden perception of the role of the aquaecosystem beyond serving simply as a source of income for the fish farmer. It can demonstrate its place as a support for biodiversity, landscape quality and hydrological regulation (water quality and flow), which are not perceived per se, but are crucial for ecosystem and regional characteristics and functioning. Promoting these services helps legitimize the production system and may facilitate adoption of practices adapted to provide more services. Nonmarket ecosystem services are essential for integrating aquaculture into territories, especially their social and environmental aspects. This principle directly connects to the first and third principles of the EAA (Soto et al. 2008): aquaculture development and management should consider the full range of ecosystem functions and services, and aquaculture should be developed within the context of other sectors, policies and goals.

\section{Adapt mechanisms and instruments for territorial governance and improve stakeholder participation}

The close link between ecological intensification of aquaculture and nonmarket services requires developing specific governance supports. Changes in ecological practices in production systems can be associated with risks and investments in knowledge and money, which are difficult to consider at the single-farm scale. Therefore, incentive programmes for ecosystem-service awareness and assessment, as well as financial support for adapted management practices, are required at farm and territorial levels. Specific practices, such as integrating activities and nutrient recycling among stakeholders within a territory or combining several species in the same production system, must be supported by adapted regulations. Governance of the development of ecological intensification at the 
territory level requires stakeholder involvement to build consensus or negotiate compromises. Facilitating stakeholder involvement in decision making should provide a positive context for cooperation and the development of ecological intensification. Ecological intensification can be considered as a pathway, with a range of systems applying a gradient of agroecological principles and embodying or providing different ecosystem services. Therefore, different practices and farmer profiles can be defined by considering their level of involvement in the ecological intensification approach.

\section{Multiple ecological intensification pathways}

The variety of positions towards ecological intensification we observed during the study raises questions about understanding of the concept and the ability to transform it into practices. It is essential to define eco-innovation methods to implement ecological intensification. As shown by several authors, ecological intensification requires an increase in knowledge, especially about agroecological functions and processes (Altieri \& Toledo 2011). It may require new skills in industrial ecology (Dumont et al. 2013) or information technology (Melville \& Ross 2010) because of new needs in social systems and ecological processes. Ecological intensification is also based on local and traditional knowledge, used in eco-innovations or adaptations of old practices, sustained by ecological awareness (Wezel et al. 2009). Adopting new practices or revised ancient ones requires individual and collective learning. Different pathways or levels of appropriating ecological intensification can be distinguished. For organic farming transition, Lamine and Bellon (2009) defined a typology of practices depending on motivation, with two main categories based on simple substitution of inputs or on complete system change. Using approaches developed for agriculture, we defined three

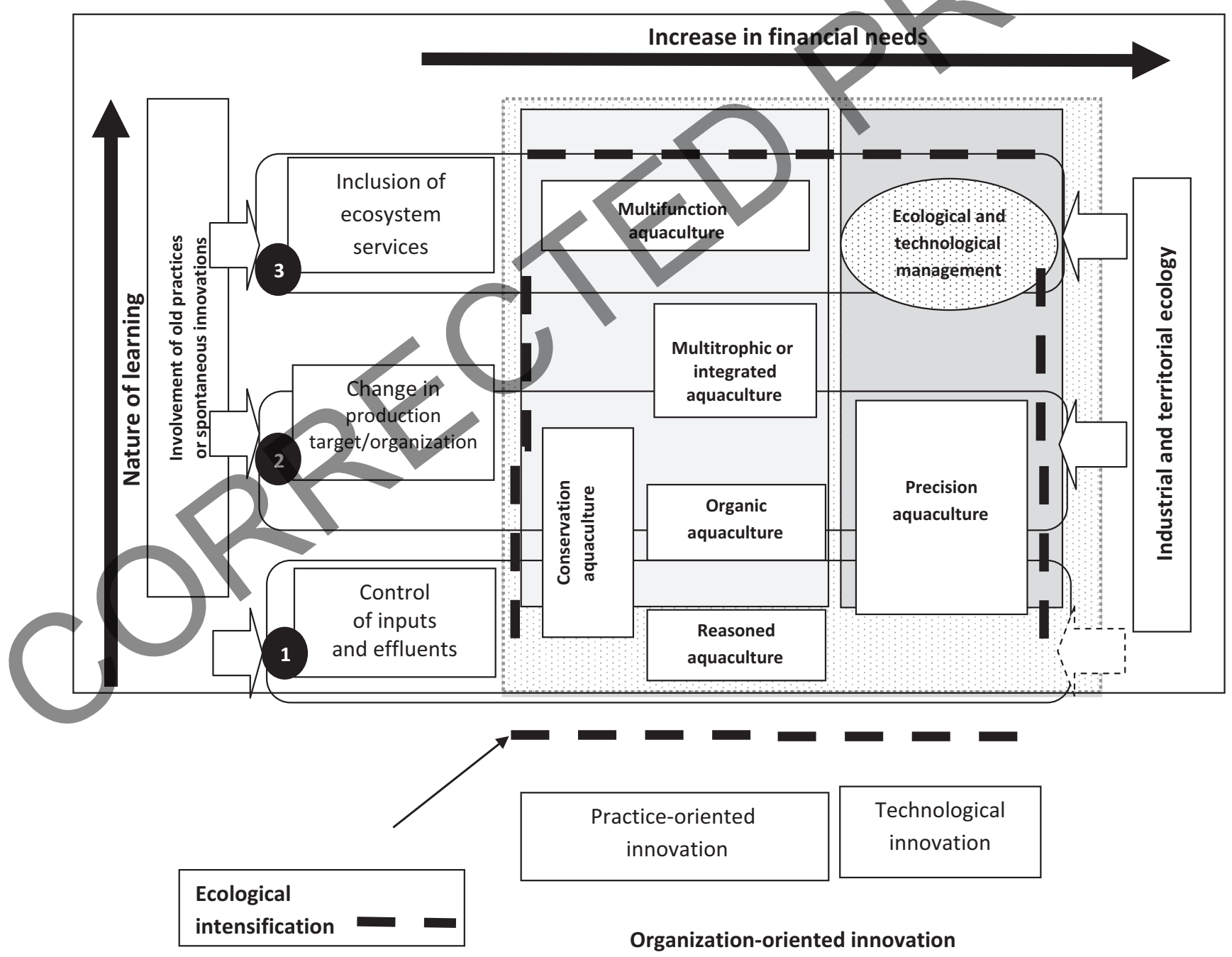

Figure 4 Pathways of system transition towards ecological intensification of aquaculture. Adapted from Rey-Valette et al. (2015). 
profiles towards ecological intensification of aquaculture (Fig. 4).

The profiles can be defined according to the nature of learning, which becomes more complex with an increase in scale or the complexity of system change (Fig. 4, bottom to top). Eco-innovations rely on better management of inputs and effluents (Profile 1). This is typically the case when adding water-treatment devices or choosing more ecofriendly sources of feed (e.g. natural biomass, as in our case studies). In a further step, changes may concern the organization and/or overall objective of the farming system (Profile 2). Innovations concern organization of the elements of the system, the addition of new subsystems and their connections with other activities. This may include the creation of a polyculture system (e.g. the Indonesian case study) or integration with other surrounding activities, such as livestock (e.g. pig and pond integration in Brazil) or a cropping system in which outlet water from fish farms is used to irrigate and fertilize crops (e.g. paddy fields and vegetable crops in Indonesia). This integration can encourage the design of new systems, such as aquaponics (integration of fish and plant cultures in a recirculating water system). The next step in differentiating systems according to ecological intensification is introducing ecosystem services into production-system design (Profile 3 ). This step requires using a territorial approach to account for an increase in scale. All dimensions of the aquaecosystem may be involved in the design, especially distant receiving and resource ecosystems. Integration of regulation and support services, especially those concerning ecosystem quality and biodiversity or hydrology regulation, require specific support as they are nonmarket ecosystem services (e.g.in pond systems in France). Defining these services might require the involvement of external stakeholders. Cultural services are easier to include because some are market oriented, such as hunting and angling in French ponds or 'PesquePage' (fish and pay) in Brazil.

The knowledge required differs according to the type of innovation (Fig. 4, left to right), from a simple change in practices to the introduction of new technologies, such as producing algae using effluents from a salmon RAS. Partnership with technical or research institutes may be required. Complex factors determine pathways to ecological intensification. For eco-innovation in agriculture, two types of factors are generally distinguished: those considered at the farm scale and those that depend on institutional position and derived governance rules.

\section{Conclusion and perspectives}

A territorial approach is essential in ecological intensification to understand ecosystem services, but it also raises questions about territorial management and space sharing.
The debate on land use and land-sharing/sparing approaches must be considered when planning activities within a territory, between intensive and extensive areas, or between productive and protected areas. The consequences for biodiversity, productivity and ecosystem services are not obvious. The scale at which these land-sparing/sharing concepts are applied is also not obvious: at the farm level (organization of land use and subsystems), at the landscape level (organization of production systems or productive and nonproductive areas) and at the territory level (organization of activities, complementarities and possible compensations). Therefore, adapting governance to support development of these systems is a real challenge. Unfortunately, current standards can become a problem: they help in defining concepts and practices and in selecting and supporting some of them, but they limit the combination of practices and the evolution of design possibilities. An initial step might include suspending the definition of standards, which would help fish farmers enter a pathway to ecological intensification, even if it limits possibilities for labelling and financial support in the short term.

Combining agroecology principles and ecosystem services in ecological intensification appears useful for modifying aquaculture practices to address issues surrounding development of aquatic products while preserving the environment. This approach helps establish guidelines and conceptual frameworks to implement ecological intensification of fish farming. Using case studies helps confirm the operational value of the concept and understand how stakeholders appropriate and transform it into innovation. The ecological intensification methods developed in agriculture are adaptable to aquaculture, which already has a range of traditional practices and concepts that correspond with concepts of agroecology (e.g. polyculture, integrated livestock and pond systems).

Nevertheless, this concept promotes a wide range of practices that have to be adapted and combined depending on contexts (i.e. social, economic and environmental) of the aquaecosystem. There is no single pathway. Pathways can include incremental and continual improvements, but can also include completely new breakthroughs in production-system design.

The existence of a specific type of biodiversity in aquatic systems, at the interface between water, soil and air, is a particular opportunity to build systems using or sustaining this biodiversity and its associated functions and services. There is room in production-system improvement to exploit the complexity of ecosystems. This will require a change in perspective in production-system design and the involvement of knowledge from scientific communities (especially ecology), farmers and other stakeholders. Numerous questions remain about ecological intensification of fish farming. Nevertheless, this concept will help to 
change society's perception of fish farming and guide this essential activity towards more sustainable development.

\section{Acknowledgements}

The authors thank the fish farmers and their professional organizations in Muara Jambi (Indonesia), Santa Catarina (Brazil), Loraine and Brenne (France) and the BDV Company (France) for their collaboration. We thank many others for their assistance with the surveys and their support of the study: Yann Moreau (IRD), Jérôme Lazard (CIRAD), Yannick Ledoré (U. de Lorraine), Jean Noël Gardeur (U. de Lorraine), Mimid Abdul Hamid (BBAT Jambi), Dafzel Day (BBAT Jambi), Nicolas Belhamiti, Melaine Loch, Jehanne Prudhomme, Killian Chary, Mathieu Adam, Julie Simon, Nancy Blanc, Lisa Briot, Stéphanie Guérin and Lionel Dabbadie. Finally, the authors acknowledge the French National Research Agency (ANR-09-STRA-08) for its financial support.

\section{References}

Altieri AM (1995) Agroecology, The Science of Sustainable Agriculture, p. 433. Westview Press, Inc., Boulder, CO.

Altieri MA (1999) The ecological role of biodiversity in agroecosystems. Agriculture Ecosystems \& Environment 74: 19-31.

Altieri AM (2002) Agroecology: the science of natural resource management for poor farmers in marginal enyironments. Agriculture Ecosystems and Environment 93: 1-24.

Altieri MA, Toledo VM (2011) The agroecological revolution in Latin America: rescuing nature, ensuring food sovereignty and empowering peasants. Journal of Peasant Studies 38: 587612.

Aubin J (2013) Life Cycle Analysis as applied to environmental choices regarding farmed or wildcaught fish. CAB Reviews: Perspectives in Agriculture, Veterinary Science, Nutrition and Natural Resources 8 (11): 1-10.

Aubin J, Papatryphon E, van der Werf HMG, Chatzifotis S (2009) Assessment of the environmental impact of carnivorous finfish production systems using life cycle assessment. Journal of Cleaner Production 17: 354-361.

Aubin Y, Rey-Valette H, Mathé S, Wilfart A, Legendre M, Slembrouck J et al. (2014) Guide for Implementing Ecological Intensification of Aquaculture Systems, p. 131. INRA, Rennes, France.

Aubin J, Baruthio A, Mungkung R, Lazard J (2015) Environmental performance of brackish water polyculture system from a life cycle perspective: a Filipino case study. Aquaculture 435: 217-227.

Azim M, Little DC (2006) Intensifying aquaculture production through new approaches to manipulating natural food? $C A B$ Reviews: Perspectives in Agriculture, Veterinary Science, Nutrition and Natural Resources 1 (62): 1-23.

Banas D, Masson G, Leglize L, Usseglio-Polatera P, Boyd CE (2008) Assessment of sediment concentration and nutrient loads in effluents drained from extensively managed fishponds in France. Environmental Pollution 152: 679-685.

Belton B, Little D, Grady K (2009) Is responsible aquaculture sustainable aquaculture? WWF and the eco-certification of Tilapia. Society \& Natural Resources 22: 840-855.

Blayac T, Mathé S, Rey-Valette H, Fontaine P (2014) Perceptions of the services provided by pond fish farming in Lorraine (France). Ecological Economics 108: 115-123.

Bommarco R, Kleijn D, Potts SG (2013) Ecological intensification: harnessing ecosystem services for food security. Trends in Ecology \& Evolution 28: 230-238.

Bosma RH, Verdegem MCJ (2011) Sustainable aquaculture in ponds: principles, practices and limits. Livestock Science 139: 58-68.

Bosma RH, Phong LT, Kaymak U, Van den Berg J, Udo HMy, Van Mensvoort MEF et al. (2006) Assessing and modelling farmers' decision-making on integrating aquaculture into agriculture in the Mekong Delta. NJAS - Wageningen Journal of Life Sciences 53: 281-300.

Boyd CE (2003) Guidelines for aquaculture effluent management at the farm-level. Aquaculture 226: 101-112.

Casaca JM, Tomazelli O Jr, Warken JA (2005) Policultivos de peixes integrados: 0 Modelo do Oeste de Santa Catarina, p. 70. Mércur Indústria Gráfica, Chapeco.

Cassman KG (1999) Ecological intensification of cereal production systems: yield potential, soil quality, and precision agriculture. Proceedings of the National Academy of Sciences of the United States of America 96: 5952-5959.

Conway GR (1987) The properties of agroecosystems. Agricultural Systems 24: 95-117.

Costanza R, de Groot R, Sutton P, van der Ploeg S, Anderson SJ, Kubiszewski I et al. (2014) Changes in the global value of ecosystem services. Global Environmental Change 26: 152-158.

Costa-Pierce BA (ed) (2002) Ecological Aquaculture: The Evolution of the Blue Revolution, p. 382. Blackwell Science Ltd, Oxford, UK.

Costa-Pierce BA (2010) Sustainable ecological aquaculture systems: the need for a new social contract for aquaculture development. Marine Technology Society Journal 44: 88-112.

Dalgaard T, Hutchings NJ, Porter JR (2003) Agroecology, scaling and interdisciplinarity. Agriculture, Ecosystems \& Environment 100: 39-51.

De Schutter O (2010) Promotion and protection of all human rights, civil, political, economic, social and cultural rights, including the right to development. Report submitted by the Special Rapporteur on the right to food. United Nations, pp. 21.

Díaz S, Demissew S, Carabias J, Joly C, Lonsdale M, Ash N et al. (2015) The IPBES Conceptual Framework-connecting nature and people. Current Opinion in Environmental Sustainability 14: 1-16.

Doré T, Makowski D, Malézieux E, Munier-Jolain N, Tchamitchian M, Tittonell P (2011) Facing up to the paradigm of ecological intensification in agronomy: revisiting methods, concepts and knowledge. European Journal of Agronomy 34: 197-210. 
Duc NM (2008) Farmers' satisfaction with aquaculture - a logistic model in Vietnam. Ecological Economics 68: 525-531.

Dumont B, Fortun-Lamothe L, Jouven M, Thomas M, Tichit M (2013) Prospects from agroecology and industrial ecology for animal production in the 21 st century. Animal 7 (6): 10281043.

Edwards P (2015) Aquaculture environment interactions: past, present and likely future trends. Aquaculture 447: 2-14.

FAO (2006) Livestock's Long Shadow, Environmental Issues and Options, p. 390. FAO, Roma.

FAO (2014) The State of World Fisheries and Aquaculture: Opportunities and Challenges, p. 243. Food and Agriculture Organisation of United Nations, Rome.

Foresight (2011) The Future of Food and Farming, p. 211. The Government Office for Science, London.

Frischknecht R, Jungbluth N, Althaus HJ, Doka G, Dones R, Hirschier R et al. (2004) Implementation of life cycle impact assessment methods (version 1.1). Eco-Invent Report No. 3. Swiss Centre for Life Cycle Inventories, Dübendorf, 2004. pp 116.

Gaillard J, Thomas M, Lazartigues A, Bonnefille B, Pallez C, Dauchy X et al. (2015) Potential of barrage fish ponds for the mitigation of pesticide pollution in streams. Environmental Science and Pollution Research 23: 23-35.

Garbach K, Milder JC, Montenegro M, Karp DS, DeClerck FAJ (2014) Biodiversity and ecosystem services in agroecosystems. In: Alfen NKV (ed.) Encyclopedia of Agriculture and Food Systems, pp. 21-40. Academic Press, London.

Griffon M (2006) Nourrir la planète, p. 455. Odile Jacob, Paris, France.

Griffon M (2010) Pour des agricultures écologiquement intensives. Editions de l'Aube, La Tour d'Aigues, France.

Griffon M (2013) Qu'est-ce que l'agriculture écologiquement intensive? Quae, Paris.

Guinée JB, Gorrée M, Heijungs R, Huppes G, Kleijn R, de Koning A et al. (2002) Handbook on Life Cycle Assessment. An Operational Guide to the ISO Standards, p. 692. Kluwer Academic Publishers, Dordrecht, The Netherland.

Haines-Young R, Potschin M (2013) Common international classification of ecosystem services (CICES): Consultation on Version 4, August-December 2012. 33pp. EEA Framework Contract No EEA/IEA/09/003.

Hasan MR, Chakrabarti R (2009) Use of Algae and Aquatic Macrophytes as Feed in Small-scale Aquaculture: A Review (No. 531). Food and Agriculture Organization of the United Nations (FAO), Rome.

Henriksson PJG, Guinée JB, Kleijn R, Snoo GR (2011) Life cycle assessment of aquaculture systems - a review of methodologies. The International Journal of Life Cycle Assessment 17: 304-313.

Huet M (1956) Aperçu de la pisciculture en Indonésie. Bulletin Agricole du Congo Belge XLVII (4): 901-957.

ISO (2006a) Environmental Management - Life Cycle Assessment - Principles and Framework, p. 32. ISO 14040, ISO, Geneva.
ISO (2006b) Environmental Management - Life Cycle Assessment - Requirements and Guidelines, p. 58. ISO 14044, ISO, Geneva.

Joffre OM, Bosma RH, Ligtenberg A, Tri VPD, Ha TTP, Bregt AK (2015) Combining participatory approaches and an agent-based model for better planning shrimp aquaculture. Agricultural Systems 141: 149-159.

Kaplowitz MD (2000) Identifying ecosystem services using multiple methods: lessons from the mangrove wetlands of Yucatan, Mexico. Agriculture and Human Values 17: 169-179.

Kaplowitz MD, Hoehn JP (2001) Do focus groups and individual interviews reveal the same information for natural resource valuation? Ecological Economics 36: 237-247.

Kumar M, Kumar P (2008) Valuation of the ecosystem services: a psycho-cultural perspective. Ecological Economics 64: 808819.

Lamine C, Bellon S (2009) Conversion to organic farming: a multidimensional research object at the crossroads of agricultural and social sciences. A review. Agronomy for Sustainable Development 29: 97-112.

Landers DH, Nahlik AM (2013) Final Ecosystem Goods and Services Classification System (FEGS-CS). Epa United States Environmental Protection Agency, Washington, DC.

Larsson J, Folke C, Kautsky N (1994) Ecological limitations and appropriation of ecosystem support by shrimp farming in Colombia. Environmental Management 18: 663-676.

Lazard J, Baruthio A, Mathé S, Rey-Valette H, Chia E, Aubin J et al. (2009) Adaptation of aquaculture system typologies to the requirements of sustainable development. Cahiers Agricultures 18: 199-210.

Malézieux E (2012) Designing cropping systems from nature. Agronomy for Sustainable Development 32: 15-29.

Martins CIM, Eding EH, Verdegem MCJ, Heinsbroek LTN, Schneider O, Blancheton JP et al. (2010) New developments in recirculating aquaculture systems in Europe: a perspective on environmental sustainability. Aquacultural Engineering 43: 83-93.

Mathé S (2014) Integrating participatory approaches into social life cycle assessment: the SLCA participatory approach. The International Journal of Life Cycle Assessment 19: 1506-1514.

Mathé S, Rey-Valette H (2015) Local knowledge of pond fishfarming ecosystem services: management implications of stakeholders' perceptions in three different contexts (Brazil, France and Indonesia). Sustainability 7: 7644-7666.

Mathevet R, Thompson J, Delanoë O, Cheylan M, Gil-Fourrier C, Bonnin M (2010) La solidarité écologique: un nouveau concept pour la gestion intégrée des parcs nationaux et des territoires. Natures Sciences Sociétés 18: 424-433.

Mazumder D, Lorenzen K (1999) Developing aquaculture of small native species (SNS) in Bangladesh: village level agroecological change and the availability of SNS. Naga, The ICLARM Quarterfly 22(3): 20-23.

Melville NP, Ross SM (2010) Information systems innovation for environmental sustainability. MIS Quarterly 34: 1-21. 
Millennium Ecosystem Assessment (2005) Ecosystems and Human Well-being: Synthesis, p. 155. (ed Island Press). World Resources Institute, Washington, DC.

Naylor RL, Goldburg RJ, Primavera JH, Kautsky N, Beveridge MCM, Clay J et al. (2000) Effect of aquaculture on world fish supplies. Nature 405: 1017-1024.

Nhan DK, Phong LT, Verdegem MJC, Duong LT, Bosma RH, Little DC (2007) Integrated freshwater aquaculture, crop and livestock production in the Mekong delta, Vietnam: determinants and the role of the pond. Agricultural Systems 94: 445-458.

Nhan DK, Verdegem MCJ, Binh NT, Duong LT, Milstein A, Verreth JAJ (2008) Economic and nutrient discharge tradeoffs of excreta-fed aquaculture in the Mekong Delta, Vietnam. Agriculture, Ecosystems \& Environment 124: 259-269.

Odum HT, Peterson N (1996) Simulation and evaluation with energy systems blocks. Ecological Modelling 93: 155-173.

Pant J, Demaine H, Edwards P (2004) Assessment of the aquaculture subsystem in integrated agriculture-aquaculture systems in Northeast Thailand. Aquaculture Research 35: 289-298.

Papatryphon E, Petit J, Kaushik SJ, van der Werf HMG (2004) Environmental impact assessment of salmonid feeds using life cycle assessment (LCA). AMBIO: A Journal of the Human Environment 33: 316-323.

Pelletier N, Tyedmers P (2008) Life cycle considerations for improving sustainability assessments in seafood awareness campaigns. Environmental Management 42: 918-931.

Pelletier NL, Ayer NW, Tyedmers PH, Kruse SA, Flysjo A, Robillard G et al. (2007) Impact categories for life cycle assessment research of seafood production systems: review and prospectus. International Journal of Life Cycle Assessment 12: 414-421.

Petersen B, Snapp S (2015) What is sustainable intensification? Views from experts. Land use Policy 46: 1-10.

Petrosillo I, Costanza R, Aretano R, Zaccarelli N, Zurlini G (2013) The use of subjective indicators to assess how natural and social capital support residents quality of life in a small volcanic island. Ecological Indicators 24: 609-620.

Phong LT, van Dam AA, Udo HM), van Mensvoort MEF, Tri LQ, Steenstra FA et al. (2010) An agro-ecological evaluation of aquaculture integration into farming systems of the Mekong Delta. Agriculture, Ecosystems \& Environment 138: 232-241.

Pucher J, Steinbronn S, Mayrhofer R, Schad IE-MM, Focken U (2013) Improved sustainable aquaculture systems for small-scale farmers in northern Vietnam. In: Fröhlich HL (ed.) Sustainable Land Use and Rural Development in Southeast Asia: Innovations and Policies for Mountainous Areas, pp. 281-317. Springer, Berlin, Heidelberg.

Quétier F, Rivoal F, Marty P, de Chazal J, Thuiller W, Lavorel S (2010) Social representations of an alpine grassland landscape and socio-political discourses on rural development. Regional Environmental Change 10: 119-130.

Rey-Valette H, Mathé S, Chia E, Aubin J (2015) Quels types d'éco-aquaculteurs face á l'intensification écologique? L'exemple de l'aquaculture en étang en France et au Brésil. Revue d'Etudes en Agriculture et Environnement 96(2): 313-337.
Soto D, Aguilar-Manjarrez J, Brugère C, Angel D, Bailey C, Black $\mathrm{K}$ et al. (2008) Applying an ecosystem-based approach to aquaculture: principles, scales and some management measures. In: Soto D, Aguilar-Manjarrez J, Hishamunda N (eds) Building an Ecosystem Approach to Aquaculture, pp. 15-35. FAO, Rome. FAO/Universitat de les Illes Balears, Expert Workshop. 7-11 May 2007, Palma de Mallorca, Spain. FAO Fisheries and Aquaculture Proceedings. No. 14.

Steffen W, Richardson K, Rockstrom J, Cornell SE, Fetzer I, Bennett EM et al. (2015) Planetary boundaries: guiding human development on a changing planet. Science 347: 1259855.

Sukhdev P, Wittmer H, Schröter-Schlaack C, Nesshöver C, Bishop J, ten Brink P et al. (2010) The economics of ecosystems and biodiversity: mainstreaming the economics of nature: a synthesis of the approach, conclusions and recommendations of TEEB. UNEP, Geneva, Switzerland. 39pp. ISBN 978-3-9813410-3-4.

Tacon AGJ, Metian M, Turchini GM, Silva S (2010) Responsible aquaculture and trophic level implications to global fish supply. Reviews in Fisheries Science 18: 94-105.

Troell M, Joyce A, Chopin T, Neori A, Buschmann AH, Fang JG (2009) Ecological engineering in aquaculture - potential for integrated multi-trophic aquaculture (IMTA) in marine offshore systems. Aquaculture 297: 1-9.

Troell M, Naylor RL, Metian M, Beveridge M, Tyedmers PH, Folke C et al. (2014) Does aquaculture add resilience to the global food system? Proceedings of the National Academy of Sciences 111: 13257-13263.

Tsuruta T, Yamaguchi M, Abe SI, Iguchi KI (2011) Effect of fish in rice-fish culture on the rice yield. Fisheries Science 77(1): 95-106.

Wezel A, Bellon S, Dore T, Francis C, Vallod D, David C (2009) Agroecology as a science, a movement and a practice. A review. Agronomy for Sustainable Development 29: 503-515.

Wilfart A, Corson MS, Aubin J (2012a) Emergy accounting: principles and application for environmental assessment of agricultural and animal production systems. INRA Productions Animales 25: 57-65.

Wilfart A, Merle T, Mathé S, Aubin J (2012b) PISC'n'TOOL: an operational tool for assessing sustainability in aquaculture systems. In: 8th International Conference on LCA in the Agri-Food Sector (ed INRA), Saint Malo, France.

Wilfart A, Prudomme J, Blancheton JP, Aubin J (2013) LCA and emergy accounting of aquaculture systems: towards ecological intensification. Journal of Environmental Management 121: 96-109.

Zhao Y, Fang Y, Jin Y, Huang J, Bao S, Fu T et al. (2014) Potential of duckweed in the conversion of wastewater nutrients to valuable biomass: a pilot-scale comparison with water hyacinth. Bioresource technology 163: 82-91.

\section{Supporting Information}

Additional Supporting Information may be found online in the supporting information tab for this article: 
Figure S1. Farmers' and other stakeholders' perceptions of provisioning services at the study sites.

Figure S2. Farmers' and other stakeholders' perceptions of regulation and support services at the study sites.

Figure S3. Farmers' and other stakeholders' perceptions of cultural services at the study sites.

Tables S1. Number of individuals surveyed in stakeholder groups to analyze perceptions of ecosystem services.
Tables S2. Classification of environmental flows used in Emergy accounting: description of inputs and services according to Cavalett et al. (2006).

Tables S3. Emergy indicators used in environmental accounting according to Brown and Ulgiati (1997) and Cavalett et al. (2006).

Tables S4. Values of LCA impact categories and Emergy indicators calculated for each study site.

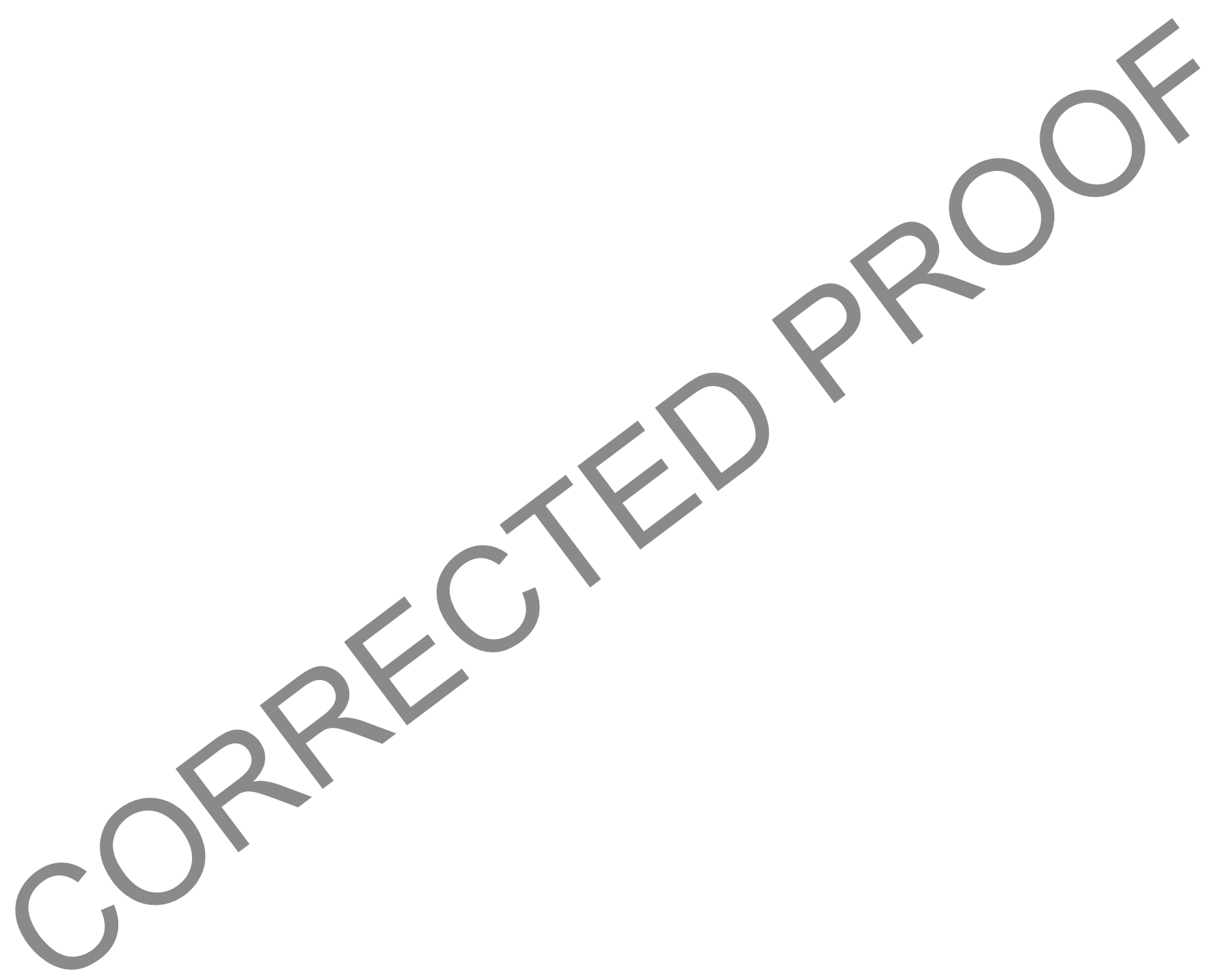

